\title{
TERRITÓRIOS AUTÔNOMOS ZAPATISTAS: ESBOÇOS DE UMA GEOGRAFIA ALTERNATIVA ${ }^{1}$
}

\author{
TERRITORIOS AUTONOMOS ZAPATISTAS: ESBOZOS DE UNA \\ GEOGRAFÍA ALTERNATIVA
}

ZAPATISTAS AUTONOMOUS TERRITORIES: SKETCHES OF AN ALTERNATIVE GEOGRAPHY

\author{
Fábio Márcio Alkmin² \\ Graziela Menezes de Jesus ${ }^{3}$
}

\begin{abstract}
RESUMO: Observa-se nas últimas três décadas a emergência política de diversas organizações indígenas nos países latino-americanos. No bojo desse fenômeno, o Exército Zapatista de Libertação Nacional (EZLN) levantou-se publicamente em armas no ano de 1994, em Chiapas, México. O EZLN destacou-se dos demais movimentos indígenas não só pelo uso das armas, mas também por suas estratégias discursivas e propostas alternativas ao indigenismo integracionista até então levado a cabo pelo Estado mexicano. Entre as demandas já "tradicionais" dos povos indígenas, como a questão da permanência à terra, o movimento zapatista incluiu em sua pauta política a reivindicação por autonomia, entendida, nesse contexto, como um distinto regime jurídico-territorial que permita aos povos indígenas mexicanos o exercício concreto da autodeterminação. Após o fracasso na aprovação de uma lei que definisse os marcos legais desse regime autonômico, os zapatistas decidem consolidar unilateralmente a autonomia que já vinham desenvolvendo em suas comunidades, desde o final de 1994. A partir dessa "autonomia em resistência" suprimiram qualquer tipo de relação com o Estado. As mudanças dessas relações de poder se projetaram no espaço, onde, a partir da conformação de comunidades, municípios e zonas autônomas, criaram-se governos paralelos zapatistas, operantes até a presente data. Uma descrição detalhada da formação, estrutura e administração político-territorial da autonomia zapatista é o objeto do presente artigo.
\end{abstract}

Palavras-chave: Autonomia, Território, Movimentos indígenas, América Latina, EZLN

RESUMEN: Observase en las tres ultimas décadas el surgimiento de diversas organizaciones indígenas en los países de Latinoamérica. Parte de este fenómeno, el Ejército Zapatista de Liberación Nacional (EZLN) se levantó públicamente en armas en el año de 1994, en Chiapas, México. El EZLN se destacó de los otros movimientos indígenas no sólo por el uso de las armas, sino también por sus estrategias

1 Artigo resultado da pesquisa de mestrado de Fábio Alkmin: Por uma geografia da autonomia: a experiência de autonomia teritorial zapatista em Chiapas, México, 2015, DGFFLCH/USP, realizada no ambito do Programa de Pós-graduação em Geografia Humana, sob orientação do Prof. Dr. Rodrigo Valverde. Esta pesquisa contou com o financiamento da Fapesp e a parceria do Centro de Investigaciones sobre América Latina y el Caribe (Cialc), da Universidad Nacional Autónoma de Mexico (Unam). Os itens 3, 4 e 5 são de autoria de Fábio Alkmin, o item 2 é de autoria de Graziela Menezes de Jesus, os itens 1 e 6 são de autoria de ambos.

2 Mestre em Geografia Humana pela Universidade de São Paulo. Email:alcamino13@gmail.com.

${ }^{3}$ Doutora em História Social das Relações Políticas pela Universidade Federal do Espírito Santo. E-mail: grazimenezes17@gmail.com. 
discursivas y propuestas alternativas al indigenismo integracionista, hasta entonces llevado a cabo por el Estado mexicano. Entre las demandas ya "tradicionales" de los pueblos indígenas, tales como la cuestión de la permanencia en la tierra, el movimiento zapatista ha incluido en su agenda política el reclamo por "autonomía", en este contexto entendida como un distinto sistema jurídico-territorial que pueda permitir a los pueblos indígenas mexicanos el ejercicio concreto de su autodeterminación. Tras el fracaso en la aprobación de una ley para definir el marco legal de este régimen autonómico, los zapatistas deciden consolidar unilateralmente la autonomía la cual ya venían desarrollando en sus comunidades, desde el final de 1994. Basándose en esta "autonomía en resistencia" suprimieron cualquier tipo de relación con el Estado. Los cambios en estas relaciones de poder se proyectaron en el espacio, donde, por medio de la conformación de comunidades, municipalidades y regiones autónomas, se han establecido gobiernos paralelos zapatistas, en operación hasta la presente fecha. Una descripción detallada de la formación, estructura y administración político- territorial de la autonomía zapatista es el objeto de este artículo.

Palabras-clave: Autonomía, Territorio, Movimientos indígenas, Latinoamérica, EZLN

ABSTRACT: In the last three decades, many indigenous organizations have emerged politically around Latin American. The watershed moment of this phenomenon was the armed uprising of the Zapatista National Liberation Army (EZLN), in Chiapas (Mexico), 1994. Between the already traditional demands posed by indigenous people, as a separate legal-territorial arrangement that would allow Mexican indigenous people the concrete exercise of self-determination. After fail to approve a law that could define this regime's legal frameworks, the Zapatistas decided to consolidate unilaterally the autonomy that has been developed in their communities, since the end of 1994. From the so-called "autonomy of resistance", they broke any sort of relation with the State. The changes of this power relationship are projected on a territory where, from the formation of communities, municipalities and autonomous regions, parallel governments have been set and still operating to that date. Therefore, a detailed description of the formation, structure and politicoterritorial administration of Zapatista autonomy is the object of this article.

Keywords: Autonomy, Territory, Indigenous Movements, Latin America, EZLN

\section{Introdução}

O Exército Zapatista de Libertação Nacional (EZLN) é uma organização de caráter político-militar, com uma composição majoritariamente indígena, localizada no estado de Chiapas, México. Publicamente conhecido a partir de 1994 e em atuação até os dias atuais, o EZLN destacou-se dos demais movimentos indígenas latino-americanos não só pelo uso das armas, mas, entre outros motivos, pelas propostas políticas que buscavam superar as contradições do indigenismo integracionista até então levado a cabo pelo Estado mexicano. 

alternativa, pp. 158-195.

Nesse sentido, os zapatistas reivindicam e vêm desenvolvendo um processo de autonomia indígena a partir de Comunidades Autônomas, que se organizam em torno de Municípios Autônomos Rebeldes Zapatistas (Marez). Estes, por sua vez, articulam-se em cinco Zonas autônomas, todas no estado de Chiapas. Negam, em todos estes territórios, qualquer tipo de heteronomia estatal.

Partindo-se de uma breve síntese histórica, é objetivo do presente artigo uma descrição detalhada da formação, estrutura e administração dos Marez (entre os anos de 2003 e 2013, aproximadamente). Busca-se com isso uma análise introdutória, porém crítica, de como esta autonomia - entendida aqui como um processo - vem se territorializando nas comunidades rebeldes zapatistas.

Os autores realizaram trabalho de campo nos territórios zapatistas entre os anos de 2012 e 2013, buscando a partir de uma experiência empírica, elementos que contribuam a uma análise contemporânea do processo de autonomia zapatista, que já leva mais de vinte anos. O embasamento teórico e histórico partiu da revisão bibliográfica já produzida sobre o tema, sobretudo nas áreas de História, Sociologia e Antropologia, visto que estudos a partir de uma perspectiva estritamente geográfica são raros, tanto no Brasil quanto no México. Coube, portanto, buscar um diálogo transdisciplinar, tentando destacar, como dito, o aspecto territorial deste processo autonômico. Vale destacar que a maior parte da bibliografia consultada é mexicana, residindo aí não só estudos acadêmicos, mas também relatos dos próprios zapatistas, disponibilizados nas publicações da chamada Escuelita Zapatista ${ }^{4}$.

Metodologicamente buscou-se compreender os processos de despossessão territorial indígena em Chiapas - uma das contradições sociais

\footnotetext{
4 A Escuelita Zapatista visou propiciar pequenas "vivências" de mexicanos e estrangeiros nas comunidades indígenas, com o fim que de que conhecessem na prática o processo autonômico zapatista. Quatro livros foram publicados nesse contexto e formam parte do curso La libertad según I@s Zapatistas. São os seguintes: Gobierno Autónomo I, Gobierno Autónomo II, Participación de las mujeres en el Gobierno Autónomo e Resistencia Autónoma. Todos eles foram escritos a partir de relatos dos próprios zapatistas e podem ser facilmente encontrados na internet.
} 
que fomentaram o surgimento do EZLN - mediante pressupostos da Geografia Histórica, especialmente a noção de formação territorial estatal (MORAES, 2000). Acerca da compreensão do fenômeno zapatista, buscou-se criticar o conceito de território como concebido na Geografia clássica, que de maneira geral tende a se limitar ao território do Estado-Nação. Valorizou-se assim concepções teóricas que entendem que as relações de poder se estendem às diversas relações sociais, não se restringindo apenas àquelas oriundas das instituições estatais (RAFFESTIN, 1993). Tendo em vista que os territórios autônomos estão espacialmente "pulverizados" e que portanto não necessariamente possuem contiguidade espacial, travamos um diálogo com o geógrafo Marcelo Lopes de Souza, que trabalha a noção de "territóriosdescontínuos" (SOUZA, 1995).

\section{Breve contextualização histórica}

O EZLN se apresenta como um movimento político organizado a partir de um sujeito étnico, a saber, os próprios indígenas. É importante ressaltar que os zapatistas buscaram ampliar seus espaços de atuação política, mostrando que mesmo sendo um movimento composto basicamente por indígenas ${ }^{5}$, as interlocuções com outros sujeitos políticos, que não o indígena, sempre estiveram na pauta política zapatista.

Em termos históricos o EZLN faz alusão à figura política de Emiliano Zapata, um dos líderes da Revolução Mexicana de 1910. No imaginário popular a figura de Zapata nos remete à ideia de mobilização e libertação do povo mexicano e, nesse sentido, os zapatistas chiapanecos utilizam o mito de Zapata para construir uma cultura política forjada na resistência e na aceitação das camadas populares. Para os historiadores Enrique Rajchenberg e Catherine Héau-Lambert, a peripécia do zapatismo contemporâneo serve para ilustrar como os movimentos populares se apropriam de uma memória coletiva preexistente, de ideologias e mitos disponíveis nessa memória, para

\footnotetext{
${ }^{5}$ Quando afirmamos a composição indígena do EZLN devemos destacar a pluralidade presente no movimento. Sabemos que o EZLN é composto por diferentes grupos étnicos de origem Maia (Tzotzil, Tzeltal, Tojolabal, Chol, Mam e Zoque) e também por alguns mestiços.
} 
legitimar suas lutas presentes (RAJCHENBERG; HÉAU-LAMBERT, 1995).

Nesse sentido, a apropriação da figura de Zapata é resultado da necessidade do movimento em dar maior legitimidade ao seu discurso, que, em termos de dominação simbólica, articula coerentemente elementos do imaginário social com seus interesses políticos. Os revolucionários mexicanos acreditam na tradição zapatista não como uma repetição do passado no presente, mas sim como uma forma de reconstruir o passado com o objetivo de resignificar as necessidades do presente (Ibidem, 1995). Ou seja, a utilização do termo zapatismo em 1994 foi um meio de construir uma identidade e herança política rebelde, pautada na tradição revolucionária mexicana.

A adoção da imagem de Zapata também é fundamental para referenciar umas das principais demandas políticas do EZLN: a luta pela terra. Em termos históricos, a Revolução Mexicana trouxe à tona uma série questionamentos sociais que incluíam a luta pela democracia (fim do porfiriato) e a luta pela terra. Uma de suas principais conquistas foi a Constituição Mexicana (1917), que trouxe consigo a promessa de reforma agrária e de reconhecimento das terras comunais através de seu "artigo 27". O artigo 27 reconhecia o solo e o subsolo como propriedades da nação,

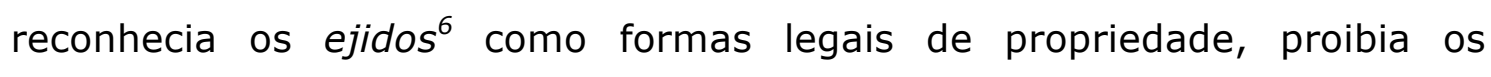
latifúndios e previa a dotação de terras expropriadas à reforma agrária.

Para o historiador Adolfo Gilly, o artigo 27 inseriu a luta camponesa pela terra nas normas constitutivas da relação estatal, fazendo com que todos os conflitos agrários depois desse período tenham sido relacionados com as interpretações e disposições desse artigo (GILLY, 2002, p. 32).

Por seu caráter periférico (política e geograficamente falando), podese dizer que a Revolução só chegou em Chiapas no ano de 1914, quando Agustín Castro chegou ao estado para destituir os funcionários porfiristas e aprovar algumas leis, entre elas a Ley de Liberación de Mozos, que abolia a

6 Forma de propriedade comunal de terras que representa um ele entre os indígenas do presente e seus antepassados. Os ejidos podem ser considerados um dos principais elementos de resistência e manutenção das identidades indígenas. 
escravidão por dívidas ${ }^{7}$ (LÉON, 1985, p. 51-52). Sentindo a possibilidade de perder privilégios de ordem política e econômica, os fazendeiros da região resolveram se organizar:

En diciembre del mismo año, los finqueros se levantaron en armas contra crímenes de los carrancistas, en defensa de la "soberanía" del estado y de los intereses de la familia chiapaneca. Para ello crearon la Brigada Libre de Chiapas e iniciaron una guerra al estilo guerrillero: ataques por sorpresa, pequeños grupos, emboscadas, vida nómada, etcétera. Esta táctica se les facilitaba por su conocimiento del territorio. El ejército de los finqueros fue conocido con el mote de mapache, porque actuaban como estos roedores, caían en las noches sobre milpas y al día siguiente el fruto había desaparecido. Eran pues una especie de animales nocturnos. A ellos se unieron los finqueros de San Cristóbal de Las Casas, liderados por otro propietario (BARRIOS; ESPONDA, 1995).

Entre 1914 e 1920 o Estado de Chiapas foi palco de diversas lutas entre carrancistas (governo federal) e mapaches (elite local). A disputa só terminou quando Venustiano Carranza foi assassinado e Álvaro Obregón assumiu o Estado mexicano e o processo de pacificação. Para Chiapas, Obregón reservou a nomeação de Tiburcio Fernández Ruiz - líder dos mapaches - para os cargos de Chefe de Operações Militares do Exército Federal e Governador de Chiapas. O mais interessante foi que nesse período a nova Constituição mexicana já estava aprovada, e com ela, o artigo 27, que determinava o fim dos latifúndios.

Por conta disso, o então governador chiapaneco criou uma inteligente manobra legal para impedir o fim do latifúndio em Chiapas: a Ley Agraria del Estado, na qual ficou determinado que só seriam considerados latifúndios as propriedades que ultrapassassem o limite de 8 mil hectares, sendo que apenas o excedente a esse número poderia ser expropriado e repartido. Além disso, a lei dava ao proprietário um prazo de seis meses para a divisão desse excedente, sendo que, caso o mesmo tivesse herdeiros - inclusive crianças em estado de amamentação - estas terras poderiam ser divididas entre os

\footnotetext{
${ }^{7}$ Não obstante a proibição de tal prática se deu em 1914, alguns autores defendem que este regime permaneceu em operação em algumas regiões isoladas de Chiapas até o início da década de 1990 (AUBRY, 2005).
} 
filhos e/ou filhas (BARRIOS; ESPONDA, 1995). Com essa medida todo o processo de reforma agrária do Estado de Chiapas ficou comprometido e a distribuição de terras só teve alguma relevância durante o governo de Lázaro Cárdenas (1934-1940).

A questão territorial e da luta de terras é fundamental para compreendermos a luta zapatista. Em seu texto "Causas da rebelião em Chiapas", o sociólogo Pablo González Casanova defende que além dos problemas advindos da concentração de terras, temos também na origem da rebelião de Chiapas a crise da hacienda tradicional e a questão da distribuição de terras (CASANOVA, 2001). O autor considera que desde a década de 1930, devido a crise da produção cafeeira, os peones acasíllados $^{8}$ foram paulatinamente "libertados" das propriedades as quais estavam agregados. Após a década de 1970, certa parte destes peones converteram-se em trabalhadores das indústrias ligadas aos setores petrolíferos e hidrelétricos, que começavam a se destacar no estado de Chiapas.

Na esperança de tentar a vida rural de forma autônoma os peones, na abordagem de Casanova (2011), dirigiram-se à região da Selva de Lacandona, que é para onde se avançava a frente de expansão econômica. Longe de resolver o problema da falta de terras, a concessão de títulos agrários na região da Lacandona por parte do governo converteu-se rapidamente em um espaço de disputa entre indígenas e madeireiros.

Em 1972 o governo reconheceu os indígenas lacandones como "legítimos donos da selva", cedendo a eles a propriedade de cerca de 614.321 hectares, excluindo desse processo as demais etnias indígenas que também habitavam a região e eram demograficamente bem maiores. Na verdade, a concessão mascarava um acordo com a Companhia Florestal Lacandona S.A., que rapidamente se apressou para conseguir o direito de extrair 35 mil metros quadrados de madeira ao ano, o equivalente a aproximadamente dez mil árvores de cedro e de acaju (Ibidem, 2011).

Esse período da história do estado de Chiapas foi marcado pelo

\footnotetext{
${ }^{8}$ Trata-se de um termo mexicano que caracteriza o regime de servidão por dívidas.
} 
aumento dos conflitos agrários e, ao mesmo tempo, pelo surgimento das primeiras organizações políticas que visavam recuperar a posse das terras. Nesse contexto, analisar os movimentos chiapanecos significa também classificá-los, uma vez que esses movimentos eram dinâmicos e em alguns casos contraditórios.

Essas organizações constituíram a força central do movimento camponês em Chiapas antes do surgimento do EZLN. Com um discurso político que oscilava entre os princípios da luta de classe, da solidariedade e da defesa dos direitos humanos, essas organizações não estavam isoladas e ainda dividiam o cenário político com as do tipo camponesa/indígena, além daquelas não-indígenas que lutavam em prol dos grupos indígenas, como ONGs e as Igrejas Católicas e Evangélicas.

As organizações do tipo camponês/indígena dinamizaram o conflito agrário ao inserir na luta por terras o discurso de resgate da(s) cultura(s), da defesa do meio ambiente e das etnias. Além disso, Villafuerte Sollís considera que essas organizações acrescentaram dois elementos fundamentais na luta em Chiapas: a aversão ao Estado e suas instituições políticas formais, como os partidos políticos e, por outro lado, a recuperação das relações com a sociedade civil, na busca de alternativas econômicas, sociais e políticas (SOLÍs, 2002, p. 200).

Também vão surgir na Selva de Lacandona organizações camponesas que assumem a responsabilidade de organizar o trabalho produtivo para superar a crise econômica, o que Ihes conferia prestígio sociopolítico, antes mesmo de o EZLN vir a ser uma possibilidade. Aproveitando-se das fissuras entre os poderes locais e nacionais, as organizações camponesas independentes se consolidaram ampliando as temáticas de luta, ressaltando as heterogeneidades e consolidando novos espaços de sociabilidade.

Se trata de procesos organizacionales que reeditan y gestan nuevos contenidos y valores, propician una dirigencia renovada e debilitan los proyectos tanto de la izquierda como los de modernización institucional, que poseen cierta estructura orgánica y tiene como referente al Estado y a los órganos de representación política formal. Esta diversificación de actores vuelve complejo el espectro sociopolítico del campo 
chiapaneco. A las estructuras organizativas que provienen de los esquemas básicos e institucionales de atención que los productores rurales de los sectores social e privado y las organizaciones independientes y radicales, hay que agregar las organizaciones que con sentido de autonomía e solidaridad se definen como la "tercera alternativa", incursionando en el ámbito productivo según nuevos paradigmas (SOLÍS, 2002, p. 204).

No início dos anos de 1970 as manifestações cresciam nos centros urbanos mexicanos, e com elas as bandeiras por uma nova revolução, mas não uma revolução como a de 1910. Alguns estudantes mexicanos, filhos do processo de "modernização" e influenciados pelo marxismo, desejavam uma revolução do tipo socialista. A reação do Estado mexicano foi a promoção de um massacre. É ponto chave nos textos que abordam as origens do zapatismo o Massacre dos estudantes em 1968 (Tlatelolco), que provocou uma fissura profunda na esquerda mexicana, demonstrando, ao mesmo tempo, a capacidade de reação do governo.

Real y simbólicamente el 68 indica el punto de una inflexión histórica. Hasta allí alcanzó el impacto legitimador de la revolución, y se inició un lento pero irrevocable proceso de disolución del pacto social sobre el que reposaba un consenso casi unánime, una hegemonía indiscutida. El régimen no pudo restañar la grieta política y moral que le causó aquel movimiento, al que tuvo que derrotar militarmente. Tampoco pudo restaurar a su favor - a pesar de los intentos del gobierno de Luis Echeverría - la ideología de la revolución mexicana, maltrecha por el disentimiento de aquellas multitudes. Miles de jóvenes en todo el país se incorporaron a la lucha contra el régimen, con un entusiasmo fortalecido porque en los años setenta emerge un vasto movimiento social protagonizado por obreros, campesinos indígenas y mestizos, burócratas, colonos, maestros, estudiantes. (RICÁRDEZ, 2001)

Os estudantes e os militantes de esquerda, confrontados com a reação do governo, tomaram diversos caminhos possíveis, desde a desistência da luta à guerrilha armada. Lembrando que, naquele momento, eram fortes as influências dos textos de Mariátegui e da Revolução Cubana, que ressaltavam a importância dos camponeses para um movimento guerrilheiro, sem nos 
esquecermos, é claro, da Igreja - através da Teologia da Libertação - e dos movimentos sindicais.

Um desses grupos de estudantes guerrilheiros, o Exército Insurgente Mexicano (EIM), optou por entrar na clandestinidade e lutar contra o governo no estado de Chiapas, após meses sem nenhuma campanha capaz de ganhar destaque no cenário político nacional. Com outros companheiros o grupo forma as Fuerzas de Liberación Nacional (FLN), agrupação fortemente influenciada pelos ideais cubanos, tendo como objetivo instaurar no México o socialismo através da luta armada. A FLN vai crescendo aos poucos ao longo da década de 1970.

Ao mesmo tempo, também em Chiapas, as organizações camponesas e indígenas crescem. Na conjuntura pós-congresso Indígena de Chiapas (1974) surge a Unión Del Pueblo, marcada pelas tendências guevarista e maoísta. Em 1975 aparece La Unión de Ejidos Quiptic Ta Lecubtesel, uma organização indígena Tzeltal que tinha como principal demanda a regularização da posse de terras dos ejidos. A Selva de Lacandona tornavase, pouco a pouco, o palco para a união de grupos políticos distintos e provenientes de diversos lugares, com múltiplas expectativas.

Em 1983 os líderes da FLN chegaram à Selva decididos a formar um exército guerrilheiro (DIÁZ-POLANCO, 1995, p. 97). O movimento afirmava claramente os ideais marxista-leninistas de tomar o poder político para os trabalhadores urbanos e do campo, instaurando o socialismo no México. Entretanto, da idealização de um projeto a sua realização, encontra-se um caminho muito grande a ser percorrido, no caso da FLN o caminho era montanhoso, desconhecido e coberto pela selva.

Os primeiros anos na selva foram os mais difíceis e os integrantes da FLN, sabendo que não possuíam conhecimentos acerca da geografia física do local, estabeleceram uma relação de troca com os indígenas. Os guerrilheiros ofereciam treinamento militar para tornar os indígenas mais aptos para defenderem suas terras das guardias blancas ${ }^{9}$ e, em troca, recebiam os suprimentos necessários para a vida na selva. Ao ser questionado sobre como

\footnotetext{
${ }^{9}$ Milícias paramilitares contratadas pelos fazendeiros da região.
} 

alternativa, pp. 158-195.

se deu o encontro entre guerrilheiros e indígenas, subcomandante Marcos, um dos porta-vozes do EZLN, diz o seguinte:

\begin{abstract}
Llegamos con la mentalidad de marxista-leninistas, como imagino que todas las organizaciones políticos militares de los años 60 y 70 en América Latina. Este pensamiento fue limado. Llegamos marxista-leninistas, y la realidad indígena empezó a limar los bordes y lo convirtió en algo redondo. Hubo un momento de supervivencia. No podíamos tender los puentes, hablar y escuchar. No entendías los códigos del otro. Como si estuvieras hablando otro idioma, pero no hubiera del otro lado un referente para traducir lo que se está diciendo. Tenías que asumir primero el código del otro, su cosmovisión y en base a eso construir el lenguaje. En el momento en que se pudo asumir esa cosmovisión y el código cultural, ya cambió mucho. No si dio propiamente ese ultimátum "no traigas eso aquí", sino un "no te entendemos". Empezó a construirse el diálogo en el momento en que ya estábamos compartiendo ideas fundamentales (SUBCOMANDANTE MARCOS, 2001).
\end{abstract}

Os guerrilheiros da FLN perceberam que não estavam lidando com grupos sociais ingênuos, mas com grupos que tinham uma tradição de luta e resistência, com muitas experiências políticas. Eles descobriram que, naquele contexto particular e naquele grupo social específico, o universalismo teórico que acreditavam não possuía capacidade efetiva de mobilização. O sociólogo francês Yvon Le Bot considera que esse momento foi decisivo para a gênese do EZLN (LE BOT, 1997, p. 18), porque só a partir daí os guerrilheiros puderam buscar com os indígenas uma relação de aprendizagem, rompendo com a educação formal que colocava o elemento indígena sempre como sujeito passivo das relações sociais.

Os anos que se seguiram foram marcados pela articulação entre guerrilheiros e indígenas e pela superação de uma série de desafios que serviram para limitar a natureza e as demandas do grupo que estava surgindo. O primeiro desafio foi a fraude eleitoral de 1988. Na ocasião, o candidato do PRI, Carlos Salinas de Gortari, vence as eleições após uma pane no sistema eletrônico de apuração, que até então indicava a vitória do candidato oposicionista do Partido Revolucionário Democrático (PRD). Para alguns essa foi a maior fraude do sistema eleitoral político ocidental. 
Com a aproximação das comemorações dos 500 anos de "Descobrimento" das Américas, o EZLN organiza uma consulta entre Tzotziles, Choles, Mames, Tojolabales e Tzeltales. A grande maioria se pronuncia a favor do combate. Como forma de avaliar o apelo popular organizam uma manifestação em San Cristóbal de las Casas. Nesse mesmo ano as comunidades indígenas assumem o controle militar do EZLN e, em 1993, é formado o Comitê Clandestino Revolucionário Indígena (CCRI) ${ }^{10}$.

Nesse período a Selva Lacandona já se constituía como o cenário político do futuro levante zapatista, sendo os elementos dessa composição, conforme Adolfo Gilly, os mais variados: afirmação e experiência das identidades indígenas como organizadoras das comunidades; a persistência das comunidades, seus laços e suas crenças, o que inclui a autonomia como forma de gestão política e econômica; o acúmulo de experiências coletivas e a formação de dirigentes próprios; as relações com a Igreja Católica e com os ideias da Teologia da Libertação; a entrada de um pequeno núcleo de guerrilheiros na selva; a integração desse núcleo com as comunidades. Outros elementos pautados nas ações dos governos estadual e federal também se destacam: a integração política-financeira entre a oligarquia chiapaneca e os grupos econômicos e as decisões jurídico-políticas do governo Salinas (GILLY, 2002, p. 70-74).

Uma das medidas mais importantes do governo Salinas foi a reforma do artigo 27 da Constituição, colocando fim à possibilidade de novos processos de reforma agrária. A reforma legalizou a privatização das terras ejidais/comunais, assim a possibilidade de serem usadas como garantia de crédito. Além disso, facilitou a compra de bosques e as concessões de mineração por/para as empresas privadas. Em termos políticos concretos, a mudança na constituição foi um dos passos do governo mexicano para entrar, dois anos depois, no Tratado de Livre Comércio com os Estados Unidos e

10 Como instância superior de direção político-militar do EZLN temos o "Comitê Clandestino Revolucionário Indígena - Comandância Geral" (CCRI-CG), o qual é formado pela união dos cinco "comitês clandestinos" regionais (CCRI). O CCRI-CG é atualmente constituído por 22 comandantes indígenas (de todas as etnias e zonas geográficas abarcadas pelos zapatistas), sendo dois deles "subcomandantes", cabendo-Ihes a liderança da esfera militar zapatista, embora no contexto contemporâneo atuem mais como porta-vozes do movimento. 
Canadá (TLC), conforme palavras de Salinas, "a entrada do México no primeiro mundo".

Para as comunidades indígenas a reforma do artigo 27 representou não só a supressão de um direito conquistado após anos de luta, mas também o fim da possibilidade de adquirir legalmente a posse de suas terras, que, nesse caso, eram muito mais que um meio de subsistência. Os ejidos e as propriedades comunais eram para os indígenas um elo cultural desses povos com seus antepassados e, além disso, a terra era um dos principais elementos que facilitava as resistências e a manutenção das identidades étnicas.

Para além dos povos indígenas, as reformas neoliberais do governo Salinas atingiram os mais diversos setores da sociedade mexicana. A entrada do México no TLC significou para muitos trabalhadores a perda do emprego e a redução salarial, já que a maioria dos sindicatos aceitou as imposições do governo com receio de aumentar a crise (ANAYA PEREZ; BATISTA ZANE, 2001, p. 212).

Com a diminuição das indústrias estatais, o Estado mexicano perdeu consideravelmente sua participação na economia, paulatinamente, a iniciativa privada crescia em conjunto com os investimentos estrangeiros. De acordo com os historiadores Marco Antonio Anaya Perez e Refugio Batista Zane:

\footnotetext{
En el sexenio salinista surgieron nuevos ricos favorecidos con la reprivatización de las empresas estatales, generalmente ligados al Gobierno. El neoliberalismo afectó no solo a los campesinos y obreros sino también a las clases medias así como a los pequeños y medianos empresarios (ANAYA PEREZ; BATISTA ZANE, 2001, p. 210).
}

A estreia do EZLN no cenário político mexicano deu-se no dia $1^{\circ}$ de janeiro de 1994. A partir dessa data o governo e a sociedade mexicana se viram diante da necessidade de discutir a questão indígena, só que dessa vez 
os indígenas assumiram as rédeas da discussão ${ }^{11}$. A data escolhida para o início da sublevação coincidia com o ingresso do México no TLC. Tal ingresso representava para os indígenas a legitimação de um processo de modernização, que além de ser excludente, não respeitava a questão da identidade indígena. Em San Cristóbal de las Casas os zapatistas ocuparam as instituições públicas e distribuíram à população local e à imprensa a Declaración de la Selva de Lacandona, documento que inaugurou o diálogo entre o EZLN e a sociedade civil.

Ao longo de sua história várias etapas marcaram a luta dos zapatistas. Em sua origem, podemos assinalar a organização da Convención Nacional Democrática (CND) como um dos marcos na história do EZLN. Realizada entre 5 e 9 agosto de 1994, às vésperas das eleições que elegeu Ernesto Zedillo ${ }^{12}$, candidato do PRI, a CND teve como um dos seus maiores méritos a participação de um número significativo de membros da sociedade mexicana, interessados em discutir a "questão indígena" e o problema da democracia no México.

Tanto o plano de ação quanto a estrutura da CND foram marcadas pelas expectativas do quadro eleitoral mexicano, sendo que o principal assunto foi a discussão da constituição de um sistema político de transição rumo à democracia. Uma das possibilidades que estava em jogo era transformar a CND em uma frente cívica e social, capaz de mobilizar a população, sindicatos, movimentos sociais, frentes religiosas, entre outros, independente do contexto eleitoral, visando assim combater o que eles chamavam de "mal governo". Havia a esperança de que, ao final, a CND pudesse encaminhar as propostas a um governo de transição democrática, que então convocaria um Congresso Constituinte.

Ao final a CND não se concretizou como uma frente política e o EZLN manteve a postura de enfrentamento com o governo federal. Nesse sentido, podemos afirmar que a maior vitória da CND foi a fundação dos

\footnotetext{
11 Entendemos o 10 de janeiro de 1994 não só como a data da aparição do EZLN para a sociedade mexicana, mas também como um acontecimento histórico que assinala o início de um processo político entre o Estado mexicano e as populações indígenas deste país.

12 As eleições foram realizadas no dia 21 de agosto de 1994.
} 

alternativa, pp. 158-195.

Aguascalientes ${ }^{13}$, criado como espaços de constantes interações entre os membros do EZLN e da sociedade mexicana e internacional.

Em dezembro de 1994 o EZLN declarou a criação dos Municípios Autônomos Rebeldes Zapatistas (Marez), não só como uma forma de responder suas demandas ao governo, mas também como uma possibilidade de organização das comunidades partindo de suas necessidades internas ${ }^{14}$.

Os Marez são unidades territoriais que não correspondem aos arranjos jurídicos-territoriais dos municípios "oficiais", determinados pelo Estado, mas sim ao que é estabelecido pelas comunidades indígenas zapatistas, a partir de critérios como divisão étnica, idioma, religião, trabalho comum entre outros (ORNELAS, 2005, p. 134). O principal objetivo da criação dos Marez era o de fortalecer e organizar a vida coletiva das comunidades, de forma que fosse possível manter e aprimorar as condições de resistência. A criação dos mesmos dá início a uma nova etapa no marco político em que se insere o EZLN, uma vez que eles representaram o primeiro passo para a construção do projeto de reconhecimento da autonomia.

Em sua organização, os Marez tem nas comunidades sua unidade política elementar e no "mandar-obedeciendo"15 a base de sua prática política.

En la base de la experiencia autonómica se sitúa la comunidad con sus instancias de discusión y decisión: la reunión de todos los pobladores, los consejos de responsables y de representantes, $y$ en los lugares donde existen, las

13 O nome Aguascalientes foi escolhido como referência a Convención de Aguascalientes, realizada entre outubro e novembro de 1914. O objetivo da convenção foi debater os diferentes projetos que se apresentaram durante a Revolução Mexicana, nesse sentido, mais uma vez podemos observar um elemento de resignificação do passado nas lutas do presente.

${ }^{14}$ A implantação dos regimes autonômicos é fundamental para a distribuição do poder entre os distintos sujeitos políticos presentes nas sociedades. Observamos que, na realidade, poderíamos resumir a autonomia em 4 princípios básicos: o da unidade da nação, o de fraternidade entre os grupos étnicos que a compõem, o de igualdade entre os cidadãos dos territórios autônomos e o princípio de igualdade entre os grupos que compartilham a região autonômica (DE JESUS, 2007, p. 95).

${ }^{15}$ Este oximoro é fundamental dentro do sistema zapatista, pois implica que todo aquele que cumpra uma função pública indicada pela coletividade, seja em qual escala de governo for, faça estritamente o que foi pautado pelos acordos, consultas e deliberações daqueles a quem representa. Quem contraria o que foi combinado pode ser destituído do cargo (independente qual seja) a qualquer momento, por pedido da comunidade representada. 
autoridades tradicionales y los consejos de ancianos. A diferencia de lo que sucede un los espacios políticos "occidentales", en los de las comunidades indígenas no existe separación entre los temas que ahí se tratan: las cuestiones del trabajo son atendidas a la par de los asuntos religiosos, las cuestiones relativas a la lucha y a las relaciones con otras comunidades, etcétera. Asimismo no existe una "profesionalización" de los roles: de manera rotativa, la mayor parte de los habitantes de la comunidad ocupan un cargo (ORNELAS, 2004, p.73).

Inicialmente, a experiência autonômica dos 38 Marez serviu de base para o diálogo que se estabeleceu entre o EZLN, os conselhos indígenas, o governo federal e sociedade civil durante o período dos Diálogos de San Andrés, a solução política encontrada por estes atores para dar fim ao conflito que se desenrolava em Chiapas. Nos diálogos o regime autonômico foi discutido e pensado sob a ótica jurídica, cultural, política e territorial. Os mesmos foram intermediados pela Comisión de Concordia y Pacificación (Cocopa) e estavam divididos em 6 mesas $^{16}$, cada uma com seus respectivos grupos de trabalho.

O resultado dos Diálogos de San Andrés foram os Acuerdos de San Andrés, firmados em 16 de fevereiro de 1996 entre o EZLN e o governo federal. Estes acordos foram compromissos e propostas conjuntas firmadas entre o EZLN e o governo federal para garantir uma nova relação entre os povos indígenas, a sociedade e o Estado ${ }^{17}$. O principal objetivo dos acordos era acabar com a histórica subordinação dos indígenas no México, convertendo os acordos em concretas reformas amparadas constitucionalmente.

É importante ressaltar que, para o EZLN, os Acuerdos de San Andrés sobre Derechos e Cultura Indígena são considerados "acuerdos mínimos", uma vez que as propostas não satisfaziam todas as demandas políticas dos povos indígenas. Embora mínimos, os acordos foram marcados por uma série

\footnotetext{
${ }^{16}$ Derechos y cultura indígena (mesa 1), Democracia y justicia (mesa 2 ), Bienestar y desarrollo (mesa 3), Conciliación en Chiapas (mesa 4), Derechos de la mujer en Chiapas (mesa 5), Cese de hostilidades (mesa 6).

${ }^{17}$ As propostas são consideradas conjuntas porque tendo em vista a transformação do acordo em reformas constitucionais, ficou decidido que o governo consultaria o EZLN antes da aprovação.
} 

alternativa, pp. 158-195.

de manobras do governo mexicano - atrasos nas votações, violência, descumprimento dos acordos, exigência da deposição de armas. Em resumo o governo não cumpriu o que havia prometido, sendo até hoje o cumprimento dos referidos acordos uma demanda política zapatista.

Como forma de retaliação, o EZLN cortou definitivamente o diálogo com o governo, tendo como premissa para o retorno da negociação, o cumprimento dos Acuerdos de San Andrés. Entre abril de 2001 e janeiro de 2003 o EZLN atravessou uma fase de silêncio, resistindo cotidianamente aos ataques paramilitares aos municípios autônomos e se reorganizando para uma nova fase, marcada pelo aprofundamento do exercício da autonomia, independente de sua condição jurídica frente o governo federal mexicano. Em julho de 2003 o EZLN anuncia à sociedade mexicana a morte de Aguascalientes $^{18}$ e o nascimento dos Caracoles e das Juntas de Buen Gobierno.

\section{A situação agrária pós-1994 e a estratégia autonômica Zapatista.}

Como visto, é correto afirmar que os conflitos agrários em Chiapas foram um dos motivos do surgimento do EZLN, tendo sido a reforma agrária um dos grandes esforços zapatistas a partir da rebelião armada de 1994. À época, cerca de 245 mil ejidos representavam quase $11 \%$ da superfície total das unidades produtivas rurais chiapanecas, ao passo que quase metade das áreas agricultáveis do estado estava em mãos de pouco mais de 6 mil famílias de proprietários privados (CIACH; CONPAZ; SIPRO, 1997). Sabe-se que, entre 1993 e 1994, a demanda por terras chegava a quase 600 mil hectares, tornando-se uma bandeira de luta de diversos movimentos sociais de Chiapas (REYES RAMOS, 2004).

No bojo dos conflitos armados da insurgência zapatista, a luta pela terra não necessariamente se restringiu a uma mera demanda política, isto é, uma reforma vinda de "cima", pela iniciativa do Estado. A desconcentração

\footnotetext{
18 Aguascalientes foram espaços de troca de ideias e informações entre zapatistas e nãozapatistas, inaugurados em 1994. Além dos diálogos, Aguascalientes se converteram em centros de apoio ao EZLN.
} 
de terra deu-se também pelas vias de fato, mediante a "recuperação", por parte dos indígenas, de parcelas fundiárias espoliadas ao longo do processo de formação territorial chiapaneco.

Nesse sentido, o uso do conceito de "recuperação" de terras, utilizado pelos indígenas, não é fortuito e carrega uma forte carga simbólica e política. Parte-se da premissa de que o processo histórico de formação territorial chiapaneco não se deu em um espaço vazio, mas sim em um espaço originalmente ocupado por diversas etnias indígenas, que ali habitavam ${ }^{19}$. Desde a colonização, passando pelo período independente e sobretudo pelas ondas de modernização capitalista do século $X X$, muitas comunidades indígenas foram desterritorializadas mediante a concentração de terras em mãos privadas, sobretudo de não indígenas. Historicamente esta população foi reduzida em pequenas comunidades e explorada enquanto força de trabalho, muitas vezes nas terras que anteriormente possuíam e que foram expulsos, inclusive mediante recursos como a servidão por dívidas, como já tratado no presente texto.

A memória histórica desse processo fez com que a questão agrária se mantivesse latente não só pela questão material da falta de terras para a subsistência, mas também pela manutenção de uma territorialidade, alimentada pela forte carga simbólica dessa desterritorialização. Como salienta o geógrafo Rogério Haesbaert, a territorialidade é

também uma dimensão imaterial, no sentido ontológico que, enquanto "imagem" ou símbolo de um território, existe e pode inserir-se eficazmente como uma estratégia político-cultural, mesmo que o território ao qual se refira não esteja concretamente manifestado - como no conhecido exemplo da "Terra Prometida" dos judeus, territorialidade que os acompanhou e impulsionou através dos tempos, ainda que não houvesse, concretamente, uma construção territorial correspondente (HAESBAERT, 2007, p. 23).

\footnotetext{
${ }^{19}$ Para a noção de "formação territorial", adotamos aqui a definição de Moraes (2000, p. 51): "A construção política dessa jurisdição [estatal] pressupõe um domínio territorial efetivo sobre uma porção da superfície terrestre, a qual se qualifica como base física desse poder, expresso num aparato estatal. Entretanto, a consolidação desse amálgama entre Estado e território ocorre como um processo lento (plurissecular), no qual aquela extensão areolar tem de ser organizada e operada como um espaço político, jurídico, econômico e cultural, até resultar numa unidade tomada como evidente: um país. A esse processo, pode-se denominar de formação territorial-estatal, a forma geográfica de analisar a formação de um Estado Moderno".
} 
Assim, a ideia de "recuperação" toma um sentido concreto a partir dessa territorialidade indígena, entendida aqui enquanto dimensão simbólica e referencia territorial destes grupos (HAESBAERT, 2007). A questão agrária e territorial é tão importante em Chiapas que uma das primeiras medidas do EZLN quando declarara guerra ao governo mexicano, em 1994, foi o de incluir em seu programa político uma "lei agrária revolucionária". Esta lei, em seu capítulo terceiro, dizia exatamente o seguinte:

Serán objeto de afectación agraria revolucionaria todas las extensiones de tierra que excedan las 100 hectáreas de condiciones de mala calidad y de 50 hectáreas en condiciones de buena calidad. A los propietarios cuyas tierras excedan los límites arriba mencionados se les quitarán los excedentes y quedarán con el mínimo permitido por esta ley pudiendo permanecer como pequeños propietarios o sumarse al movimiento campesino de cooperativas, sociedades campesinas o tierras comunales (EZLN, 2003, p. 43).

A concreção desta "afetação agrária revolucionária" se deu a partir da reterritorialização destes grupos indígenas, tendo sido o EZLN responsável pela "recuperação" de cerca de 60 mil hectares de terra ${ }^{20}$. Isso se deu de forma direta, isto é, com a ocupação das mesmas pelos indígenas, que transformaram-nas em propriedades coletivas, transferidas a membros do EZLN para a produção de alimentos básicos (lembremos que a "via autonômica" se desenvolveu no desenrolar desse processo).

No entanto, este processo não foi nada pacífico. Pelo contrário, muitos dos antigos proprietários começaram a se organizar em torno de grupos paramilitares, elevando a violência em Chiapas a níveis alarmantes. A solução encontrada pelo Estado mexicano, ainda no auge dos conflitos, foi compor um fundo com recursos federais e estaduais, em nome da Secretaria da Reforma Agraria (SRA), com o objetivo de indenizar os antigos donos das

${ }^{20}$ Enquanto outras organizações indígenas e/ou camponesas de Chiapas, aproveitando-se da conjuntura política, tomaram posse de outros 43 mil hectares, aproximadamente. Conforme Pedro Faro (2013), exemplos dessas organizações são a Aric (Asociación Rural de Interés Colectivo), Ocez (Organización Campesina Emiliano Zapata) e Opez (Organización Proletaria Emiliano Zapata). 
propriedades. Vale salientar a "desorganização" desse processo, com grande dispêndio dos recursos públicos, o que limitou gravemente a potencialidade de resolução da antiga questão agrária chiapaneca. Relatam-se desde casos de privilégios ou supervalorização fundiária para proprietários com "relações" com o governo, até o agenciamento de "grupos invasores" por parte de fazendeiros, que mediante ocupações fictícias aproveitavam a oportunidade para se desfazer de terras de má qualidade. De maneira geral, pode-se dizer que a iniciativa do governo foi um bom negócio para os fazendeiros, que no mínimo receberam pela terra um valor maior que o de mercado (SOLÍs, 2006, p.96).

Enquanto isso, no outro extremo, o governo tratava de tentar aparelhar as organizações que impulsionavam estas recuperações, concedendo títulos fundiários apenas aos movimentos que se dispunham politicamente. Este foi mais um ponto de tensionamento e de clivagem social em Chiapas, pois enquanto a aproximação com o governo mexicano tendia a ser acatada por alguns movimentos sociais, era negada pelos zapatistas. Como premissa de qualquer avanço nas negociações os zapatistas exigiam o desenvolvimento dos pontos ainda em disputa nos tratados de San Andrés, além de sua própria ratificação constitucional, buscando com isso maior efetividade política do acordo.

Assim, lançando mão de uma estratégia divide et impera, o governo mexicano acabava por pressionar as bases de apoio zapatistas assentadas em terras recuperadas para que deixassem a organização, como forma de finalmente conseguirem os títulos dessas, então na "ilegalidade". Indo mais além, passou a ceder titulações de parcelas ocupadas por zapatistas à outros grupos, como tentativa de "sufocar" a base de apoio do EZLN. Estaria dada as condições para o surgimento de agrupações paramilitares ou grupos de choque chiapanecos, que buscando a expulsão dos zapatistas das terras as quais ganharam a titulação, passaram a atuar ao lado do governo, exército e aristocracia rural. Tais conflitos se prolongam até hoje em dia.

Em meio a esse imbróglio, os zapatistas, por sua vez, procederam com a divisão das terras recuperadas, redistribuindo-as entre as famílias afiliadas, a título de posse. Conforme entrevista realizada em Chiapas, atualmente essas 
terras são da organização (EZLN), ou seja, todas as terras são da organização e portanto estão sobre o controle da organização; quem esteja na organização irá ter o direito de usufruir das terras conforme os acordos que se nos deem diferentes Municípios Autônomos (Marez), nas Juntas de Bom Governo (JBG). Se saem da organização deverão desocupar as terras. E aí é onde tem existido muitas disputas pois há grupos que antes eram zapatistas e agora já não mais; nesses casos há diferentes formas de resolução, como por exemplo, um acordo com a organização de forma que recebam uma parte, ou em outros casos, em que quem deixa a organização perde a terra, pois afinal estão em uma situação de controle territorial a partir da declaração de guerra de 1994, e isso ainda não terminou ${ }^{21}$ (informação verbal) ${ }^{22}$.

Com o desenrolar dos fatos, a estratégia zapatista para sair da "ilegalidade" a qual Ihe acusava o governo parece ter sido questionar a legitimidade dessa mesma institucionalidade, através da manutenção do controle dessas terras, convertidas em "territórios autônomos". Os zapatistas passaram assim a desconhecer as "instituições oficiais governistas", ao ponto de não travar nenhum tipo de relação com as mesmas.

Se essa posição pôde parecer uma bravata utópica perante o poder do Leviatã Mexica, na prática, foi tão eficaz que embargou as grandes obras vinculadas ao Plan Puebla-Panamá, por exemplo. Entra nessa equação, não nos esqueçamos, o fundamental apoio da sociedade civil nacional e internacional e, é claro, o braço militar do EZLN, fatores que aumentaram o peso político de uma intervenção militar de "alta intensidade" em Chiapas. Criou-se assim um impasse, um espaço em disputa - não só geográfico mas também político - o qual os zapatistas parecem tê-lo preenchido cada vez mais pela ideia de autonomia. Desta forma, paradoxalmente, os territórios tornaram-se produto, meio e condição do poder autônomo zapatista.

\footnotetext{
${ }^{21}$ Ainda que existiram ou ainda existam desfiliações, esta não parece ser uma tendência. Os zapatistas comemoraram os vinte anos da insurgência demonstrando grande organização interna, e com um número de filiados, quiçá, maior que de que quando pegaram em armas.

22 Entrevista concedida por Pedro Faro a Fábio Alkmin, em 24 de janeiro de 2013, em San Cristóbal de las Casas, Chiapas, México. Pedro Faro é ativista do Centro de Derechos Humanos Fray Bartolomé de las Casas (FRAYBA).
} 


\section{Os Territórios Autônomos Zapatistas}

O conceito de território, ao menos no campo da Geografia, relacionase com o conceito de Poder. No entanto, se na Geografia Clássica esse poder dizia respeito sobretudo ao Estado - o território sempre se referindo ao território estatal -, pensadores do final do século $\mathrm{XX}$, tais como Raffestin (1993), defendiam que na verdade este poder se manifestava em uma variedade de relações sociais. O conceito de território, dessa forma, não deveria se restringir apenas àquele circundado pelas fronteiras estatais, nem a Geografia deveria se limitar a uma "Geografia do Estado"23.

Na esteira dessa crítica, o geógrafo Marcelo Lopes de Souza enfatiza a necessidade da compreensão do território como "um espaço definido e delimitado por e a partir de relações de poder" (SOUZA, 1995, p. 78). Nesta definição o "espaço" e "território" se diferenciam substancialmente: o primeiro dizendo respeito ao substrato material para o exercício dessas relações sociais de poder, enquanto o segundo tratando da projeção das relações sociais de poder nesse espaço (Ibidem, 1995, p. 97).

Cremos que esta perspectiva teórica nos ajude a elucidar o território zapatista, que, devido a uma multiplicidade de fatores, não possui contiguidade espacial e nem sempre é balizado por limites materiais fixos e estáveis $^{24}$. Isso significa que não obstante a existência de uma "zona de influência zapatista", isto é, uma área mais ou menos ampla onde o zapatismo enquanto movimento social organizado possui certa expressividade política, o "território autônomo zapatista", stricto sensu, é descontínuo, possuindo extensão (a "tessitura", nos termos de Raffestin) apenas na escala local ou comunitária ${ }^{25}$. Parece-nos correta, assim, a hipótese do sociólogo Cassio Brancaleone (2012, p. 283), de que o território

${ }^{23}$ Cremos desnecessário retomar essa discussão aqui, pois além de Raffestin tê-lo feito com grande profundidade e melhor do que poderíamos fazê-lo - em seu livro "Geografia do Poder" - o tema também foge do objetivo desse artigo.

24 Dentre estes fatores poderíamos citar, por exemplo, mais ou menos (para)militarização da área, planos sociais e sua pressão na desarticulação organizacional, coesão política zapatista, etc.

${ }^{25}$ E mesmo essa escala não está isenta de contradições, como por exemplo, comunidades onde residem zapatistas e não-zapatistas (o que não é o mesmo que antizapatistas). Nesse caso, a autonomia territorializa-se na/em parcela(s) do espaço comunitário ocupado por zapatistas. 

alternativa, pp. 158-195.

zapatista pode ser entendido "como uma federação de comunidades rebeldes em armas, afiliadas e articuladas como núcleos auto organizados".

Não é questão, fique claro, de desconsiderarmos a dialética entre espaço e sociedade, tema extremamente debatido na Geografia. Simplesmente ressaltamos o caráter relacional do poder que embasa o conceito de território, no sentido de que se trata de uma "disposição" nascida na/da relação entre atores sociais, e não estritamente entre o "homem" e o "espaço". Conclui-se daí que, ainda que o exercício desse poder se efetue sobre um determinado espaço (seja por meio do controle ou da apropriação), ele só tem sentido porque se dá em relação a outros atores sociais, em nosso caso particular, atores não zapatistas.

Isso nos permite compreender o território como "um campo de forças, uma teia ou rede de relações sociais, que a par de sua complexidade interna, define, ao mesmo tempo, um limite, uma alteridade" entre estes atores (SOUZA, 1995, p.86, grifo nosso). Nesse sentido, a noção de "territóriodescontínuo", proposta por Souza (1995, p. 93), parece dialogar profundamente com a situação concreta dos territórios zapatistas. Para o autor, um território-descontínuo pode se dar a partir da interconexão de diversos territórios contínuos:

\footnotetext{
Como cada nó de um território descontínuo é, concretamente e à luz de outra escala de análise, uma figura bidimensional, um espaço, ele mesmo um território [...] temos que cada território descontínuo é, na realidade, uma rede a articular dois ou mais territórios contínuos [...]. A complexidade dos territórios-rede, articulando, interiormente a um território descontínuo, vários territórios contínuos, recorda a necessidade de se superar uma outra limitação embutida na concepção clássica de território: a exclusividade de um poder em relação a um dado território (Ibidem, 1995, p. 94, grifo nosso).
}

Talvez a compreensão desse raciocínio torne-se mais didática a partir de um modelo gráfico. Partindo da adaptação da proposta apresentada por Souza (Ibidem), buscamos representar o "território-descontínuo" zapatista no modelo abaixo (mapa 1 ). 
181 AGRÁRIA, São Paulo, No. 19, 2013 ALKMIN, F. M. e JeSUS, G. G.

Mapa 1: 0 território-descontínuo zapatista (2013)

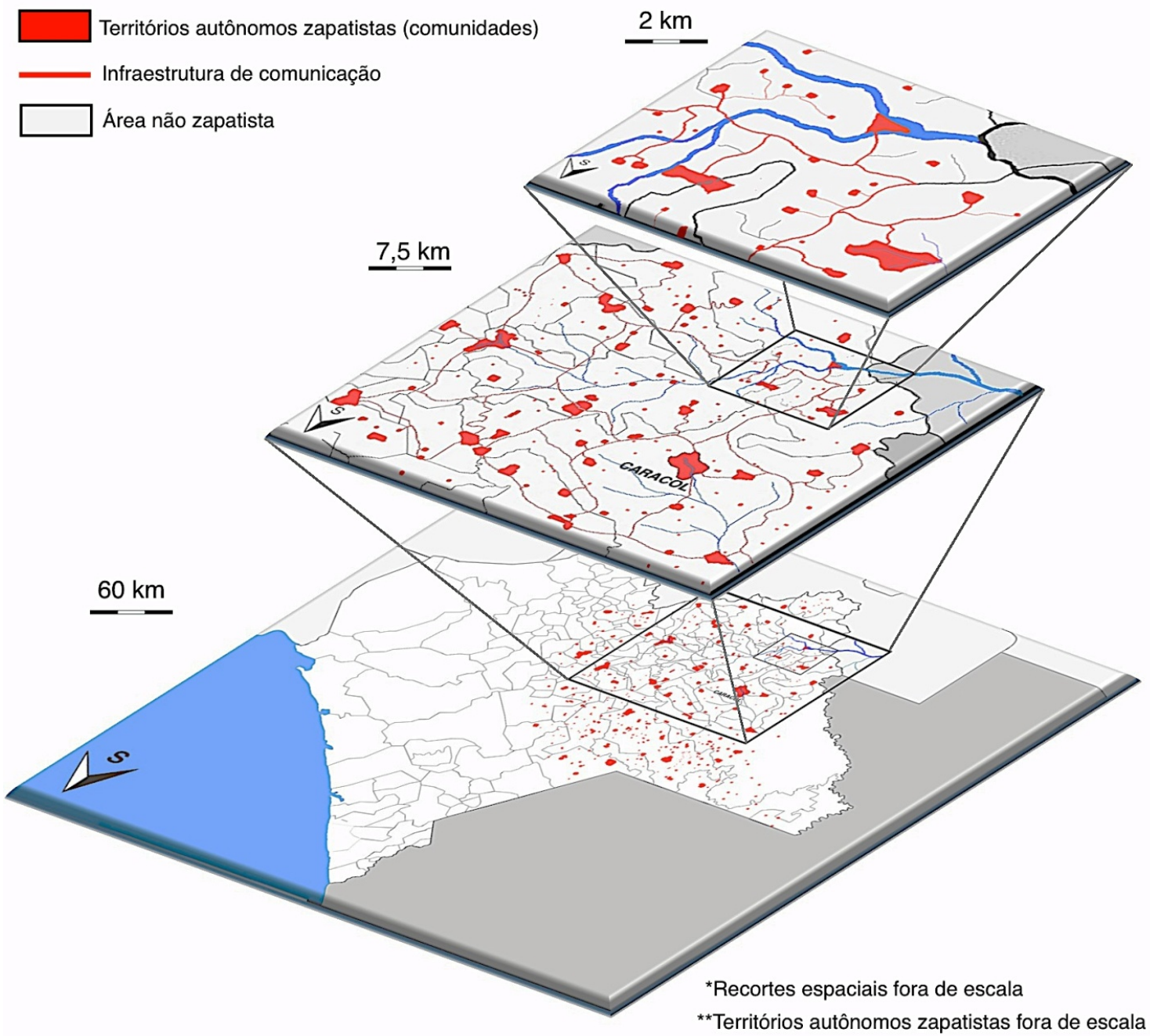

Mapa 1: O modelo acima representa o território-descontínuo zapatista, tomando 2013 como ano de referência. Em vermelho observamos os territórios pertencentes às comunidades autônomas, destinados tanto à habitação como ao cultivo agropecuário. Estas podem se interconectar pela infraestrutura presente no substrato material, como estradas que transportam bens ou pessoas (linhas em vermelho), como também por ondas de rádio, celular ou internet, no caso dos fluxos de informação. Observe-se que, quanto maior a escala, mais o território se torna contínuo, isto é, uma superfície. Em oposição, quanto menor a escala, mais ele se torna um "território-descontínuo", aparecendo como "nós" conectados por uma rede. Fonte: representação de Fábio Alkmin (2015), baseado na proposta de Souza (1995, p. 95).

Como podemos observar, o território zapatista se assemelha a uma rede, unindo os territórios das comunidades afiliadas à organização, compondo uma malha sócio-territorial complexa, que se sobrepõe - não sem 
conflitos - à estrutura territorial do estado, dita oficialista. Se observada em uma escala local, o território das comunidades autônomas desvela-se como superfície; contudo, se observada em uma escala regional, pulveriza-se, tornando-se múltiplos pontos adimensionais ou nós, todos interligados em rede (tanto a partir da infraestrutura presente no substrato material, como a partir de ondas de rádio, celular ou internet), por onde transitam bens, pessoas ou informações. Todas estas comunidades autônomas se articulam em torno dos Marez, que depois se articulam em Zonas, que totalizam cinco. Trataremos desses pontos no item que segue.

\section{Estrutura político-territorial da autonomia Zapatista}

Passemos à compreensão da estrutura político-territorial da autonomia zapatista. Visto o caráter hiperdinâmico da mesma, salientamos que tomamos o ano de 2013 como referência para a exposição. Apresentamos no organograma 1, logo abaixo, uma tentativa de síntese dessa estrutura, o qual nos servirá como guia para a explanação do sistema de governo autônomo zapatista. Ainda que pareça complexo, sua compreensão ficará mais fácil ao longo das páginas que seguem.

Devemos advertir que o organograma proposto pode conter pequenas variações ao longo dos territórios autônomos. Esta diversidade não só é fruto de contextos históricos e geográficos distintos, mas também é resultado da própria heterogeneidade étnica interna à organização, que lembremos, é composta por seis diferentes etnias ${ }^{26 .}$ Não é nossa pretensão, aqui, o estudo particularizado dessas variações, mas, para aqueles que possuem interesse nisso, recomendamos a série de quatro livros lançados no projeto Escuelita Zapatista (2013). Neles o movimento explica com detalhes o regime autonômico a partir da experiência concreta de cada zona, lançando mão de relatos dos próprios indígenas.

\footnotetext{
${ }^{26}$ Visto essa heterogeneidade, assembleias interétnicas necessitam ser feitas, na maioria das vezes, em espanhol, tentando assim facilitar o entendimento dos acordos a serem tomados.
} 
Organograma 1: Estrutura político-administrativa (civil) dos governos autônomos zapatistas em 2013

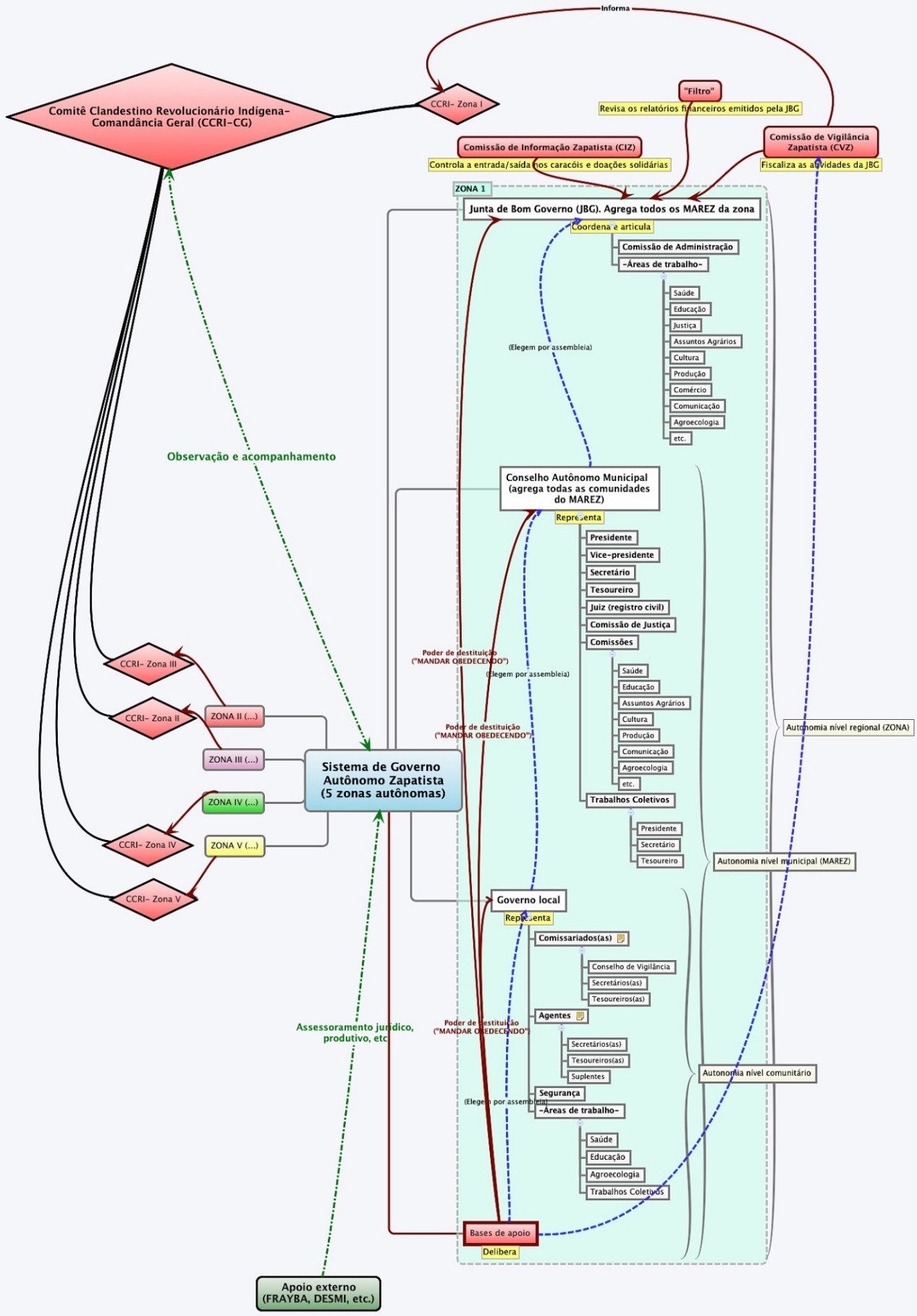

Organograma 1: A parte à direita indica a estrutura interna de uma zona. As setas azuis representam a origem dos cargos, as setas vermelhas representam sistemas de "vigilância" e controle, as setas verdes representam assessoria ou diálogo. Fonte: sistematização de Fábio Alkmin (2015), a partir de trabalho de campo, obras diversas presentes na bibliografia e material disponibilizado pelo EZLN em seu projeto Escuelita Zapatista 

alternativa, pp. 158-195.

Em primeiro lugar as diversas comunidades autônomas se agrupam em torno de 27 Marez. A quantidade de comunidades que cada município congrega é variável, podendo chegar a um total de 80 , embora a média gire em torno de pouco mais de vinte, conforme Brancaleone (2012b, p.147). Observe a tabela 1 a seguir.

Tabela 1. Organização administrativa dos Municípios Autônomos Rebeldes Zapatistas (Marez), no ano de 2013

\begin{tabular}{|c|c|c|c|}
\hline $\begin{array}{c}\text { Municípios Autônomos } \\
\text { Rebeldes Zapatistas } \\
\text { (Marez) }\end{array}$ & Caracóis & Zonas & $\begin{array}{l}\text { Etnias } \\
\text { indígenas }\end{array}$ \\
\hline $\begin{array}{c}\text { General Emiliano Zapata } \\
\text { San Pedro de Michoacán } \\
\text { Libertad de los Pueblos } \\
\text { Mayas } \\
\text { Tierra y Libertad }\end{array}$ & $\begin{array}{c}\text { Madre de los caracoles del } \\
\text { mar de nuestros sueños } \\
\text { (La Realidad) }\end{array}$ & $\begin{array}{l}\text { Selva } \\
\text { Fronteiriça }\end{array}$ & $\begin{array}{c}\text { Tojolabales, } \\
\text { Tzeltales e } \\
\text { Mames }\end{array}$ \\
\hline $\begin{array}{c}17 \text { de Noviembre } \\
\text { Lucio Cabañas } \\
\text { Comandanta Ramona }\end{array}$ & $\begin{array}{l}\text { Torbellino de nuestras } \\
\text { palabras } \\
\text { (Morelia) }\end{array}$ & Tzots Choj & $\begin{array}{l}\text { Tzeltales, } \\
\text { Tzotziles e } \\
\text { Tojolabales }\end{array}$ \\
\hline $\begin{array}{c}\text { Francisco Gómez } \\
\text { San Manuel } \\
\text { Francisco Villa } \\
\text { Ricardo Flores Magón }\end{array}$ & $\begin{array}{c}\text { Resistencia hacia un nuevo } \\
\text { amanecer } \\
\text { (La Garrucha) }\end{array}$ & Selva Tzeltal & Tzeltales \\
\hline $\begin{array}{c}\text { Vicente Guerrero } \\
\text { Trabajo } \\
\text { Francisco Villa } \\
\text { Campesino } \\
\text { La Paz } \\
\text { Benito Juárez } \\
\text { La dignidad } \\
\text { Acalbaná } \\
\text { Rubén Jaramillo }\end{array}$ & $\begin{array}{l}\text { Que habla para todos } \\
\text { (Roberto Barrios) }\end{array}$ & Zona Norte & $\begin{array}{l}\text { Choles, } \\
\text { Zoques e } \\
\text { Tzeltales }\end{array}$ \\
\hline $\begin{array}{c}\text { San Andrés Sacamch'en de } \\
\text { los Pobres } \\
\text { San Juan de la Libertad } \\
\text { San Pedro Polhó } \\
\text { Santa Catarina } \\
\text { Magdalena de la Paz } \\
16 \text { de Febrero } \\
\text { San Juan Apóstol Cancuc }\end{array}$ & $\begin{array}{c}\text { Resistencia y rebeldía por } \\
\text { la humanidad } \\
\text { (Oventik) }\end{array}$ & $\begin{array}{l}\text { Altos de } \\
\text { Chiapas }\end{array}$ & $\begin{array}{l}\text { Tzotziles e } \\
\text { Tzeltales }\end{array}$ \\
\hline
\end{tabular}

Fonte: EZLN, Gobierno Autónomo I. Cuaderno de texto de primer grado del curso de La libertad según I@s Zapatistas, 2013 (págs. 12, 24, 34, 43, 61-2, 74-5). Sistematização de Fábio Alkmin (2015). 
O Conselho Municipal é o máximo órgão de governo do Marez. Seus membros - que por sua vez são representantes das comunidades congregadas - possuem cargos representativos, não podendo portanto deliberar ações sem antes consultar, via assembleia local, os bases de apoio de suas comunidades (BRANCALEONE, 2012a, p.278). Alguns cargos possuem funções tipicamente administrativas, como o presidente, vicepresidente, secretario, tesoureiro e juiz civil (responsável pelo registro de nascimentos e óbitos, visto que os zapatistas não possuem relações com os cartórios do Estado). Soma-se, além disso, uma Comissão de Justiça, responsável por dirimir conflitos e julgar delitos ${ }^{27}$, inclusive entre não zapatistas residentes nos Marez. Finalmente, fazem parte dos Conselho Municipais as chamadas Comissões, cuja principal função é atuar em áreas de trabalho específicas, conforme as necessidades do município. Entre essas áreas destacam-se a educação e a saúde, tomadas como prioritárias. Todos os membros do Conselho possuem um mandato de três anos, medida adotada por todos os 27 Marez.

As comunidades, por sua vez, também possuem seu governo autônomo, instituído a partir da eleição de "autoridades locais". Chamamos de comunidade um conjunto de famílias vinculadas à organização, assentadas de forma mais ou menos concentrada, em número que pode variar de seis até algo em torno de uma centena, como aponta Brancaleone (Idem, 2012b, p. 145-47). O fato de uma comunidade se proclamar autônoma, fato que a vincula a algum dos Marez, não exclui ali o assentamento de famílias não vinculadas à organização zapatista, situação, aliás, bem comum. Tal cisão pode ocorrer, inclusive, no interior de um mesmo núcleo familiar. Em seus comunicados os zapatistas sempre declararam respeito a essa coexistência ${ }^{28}$, inclusive disponibilizando suas

27 O tema da justiça autônoma é amplamente complexo, não cabendo aqui mais do que pontuar sua existência. Para mais informações conferir o livro I (Gobierno Autónomo I), do curso "La libertad según I@s Zapatistas".

28 Por exemplo, nas reformas de 2003 disseram: "No es necesario ser zapatista para ser atendido y respetado por la junta de buen gobierno de los municipios autónomos. Por ser miembros de una comunidad, tienen derecho a ser atendidos. Somos hermanos de raza, color e historia. No debe haber ninguna razón para pelear y enfrentarnos. Sufrimos la misma miseria, el mismo desprecio. [...] Los zapatistas no vamos a agredir ni a imponer nada. Seremos respetuosos, sin importar partido ni organización política o religión, siempre y cuando 

alternativa, pp. 158-195.

instituições autônomas para o atendimento dessa população, fato corriqueiro na área de saúde, especialmente em regiões afastadas, onde as clínicas zapatistas cumprem um papel mais importante que os centros de saúde do próprio Estado. Não obstante essa é uma questão que inevitavelmente gera certo tensionamento intracomunitário, o que torna ainda mais complexa a prática da autonomia nesses territórios.

As situações concretas dessa complexidade variam conforme a comunidade, podendo haver uma convivência mais ou menos amistosa, situações de boicote, ou a violência concreta, em especial por grupos vinculados (direta ou indiretamente) ao governo mexicano, genericamente chamados pelos zapatistas de priistas $^{29}$. Os casos de violência podem remeter, por exemplo, a destruição de plantios das comunidades autônomas, ou ainda perseguições e assassinatos de membros zapatistas ${ }^{30}$. A resposta geralmente vem em forma de denúncias às organizações de direitos humanos, não se tendo notícia, desde a década de 1990, de um contraataque militar por parte do EZLN.

Embora esteja articulada a outros níveis de governo, a comunidade autônoma se apresenta, sem dúvida, como a base da autonomia zapatista, visto que é ali que as decisões possuem respaldo político para serem aprovadas. Isso só é possível pelo papel central que cumpre a assembleia comunitária no sistema autonômico, sem nos esquecermos da adoção incondicional do importante princípio do "mandar-obedecendo"31. Este oximoro é fundamental dentro do sistema zapatista, pois implica que todo

nos respeten, porque los pueblos indígenas podemos vivir nuestros derechos así como dicen los acuerdos de San Andrés, hechos iniciativa de ley por la Cocopa (Comisión de Concordia y Pacificación)" (COMANDANTE DAVID, 2003).

${ }^{29} \mathrm{O}$ termo se refere à afiliação ao partido PRI, ainda que muitas vezes o que na verdade existe é uma relação de aproximação com políticas sociais do Estado, independentemente de qual partido esteja no poder.

${ }^{30} \mathrm{Um}$ exemplo recente disso foi uma emboscada realizada no caracol La Realidad (na zona autônoma Selva-Fronteiriça), em maio de 2014. Nesta, além de 15 feridos, foi assassinado com um tiro à queima-roupa o professor da "Escuelita Zapatista" José Luis Solís López, vulgo Galeano. Os zapatistas acusam militantes da "Central Independiente de Obreros Agrícolas y Campesinos" (CIOAC-Histórica) pelo ataque. Informação disponível em <http://goo.gl/12sg4t>. Acesso em: 6. jun. 2014.

${ }^{31}$ Além disso, para os zapatistas, os governos autônomos - em todos seus diferentes níveis e funções - devem obedecer sete princípios operativos: Servir e não se servir (I); Representar e não suplantar (II); Construir e não destruir (III); Obedecer e não mandar (IV); Propor e não impor (V); Convencer e não vencer (VI); Baixar e não subir (VII). 
aquele que cumpra uma função pública indicada pela coletividade, seja em qual escala de governo for, faça estritamente o que foi pautado pelos acordos, consultas e deliberações daqueles a quem representa. Quem contraria o que foi combinado pode ser destituído do cargo (independente qual seja) a qualquer momento, por pedido da comunidade representada.

Os jovens de 12 a 15 anos possuem voz nas comunidades zapatistas, mas não voto. Os que possuem 16 anos ou mais, não só possuem voz e voto (homens e mulheres), como também podem assumir cargos nos governos autônomos (FERNÁNDEZ, 2009). Dessa maneira, como salienta o sociólogo Cassio Brancaleone, a assembleia comunitária torna-se um

[...] eixo de organização da vida política e social zapatista. Todas as decisões coletivas tendem a orbitar ao redor da instituição da assembleia, desde a elaboração de propostas para o plantio em áreas coletivas, o encaminhamento de sugestões e consultas dos municípios ou JBG's, a colonização de faixas de terras por novos indivíduos, a alternância das faixas de terras para descanso ou realocação entre famílias, o uso dos bosques e recursos naturais, as propostas de trabalho com a sociedade civil, o conflito entre cônjuges, as disputas pessoais, a organização de festas e atividades religiosas, etc. Algumas questões podem ser encaminhadas para outros fóruns e espaços, quando a comunidade se crê incapaz de solucioná-las (especialmente no que tange a aplicação da justiça, muitas vezes o espaço do munícipio, com a presença de membros de outras comunidades, parece depositário de maior legitimidade e parcialidade). De toda forma, a busca do consenso é a chave de operação das assembleias zapatistas, o que significa que geralmente, se uma discussão é delicada, uma assembleia pode correr o curso de prolongadas sessões. (BRANCALEONE, 2012a, p. 285)

Por consequência, o nível comunitário é o que apresenta maior diversidade no funcionamento de sua autonomia, já que suas regras, cargos e instituições devem ser "maleáveis" o suficiente para se adaptarem às particularidades locais. Embora isso traga dificuldades em uma pretensa sistematização, tentaremos aqui esboçar uma explicação baseada nos trabalhos de campo dos autores e nos comunicados dos próprios zapatistas.

De maneira geral os cargos comunitários se dividem em quatro principais atividades: comissariado(a), agente, "segurança" e as "comissões". A principal função do(a) comissariado(a) é a de 
"encaminhar os procedimentos de resolução dos conflitos agrários e discutir com a comunidade projetos produtivos relacionados à ocupação da terra" (BRANCALEONE, 2012b, p. 146). O(a) agente é responsável por representar a comunidade no âmbito de governo superior, isto é, nos Conselhos Municipais. A atividade de "segurança", pouco comentada nos textos, parece ser composta por "comandantes" civis zapatistas, que como o próprio nome indica, incumbem-se da segurança da comunidade. Alguns textos comentam que esta função é cumprida pelo chamado responsable, termo que remete aos primórdios da organização zapatista, quando ainda atuavam na clandestinidade. Os responsables muitas vezes atuavam no corpo de milicianos zapatistas e possuíam vínculos com o Comitê Clandestino Revolucionário Indígena (CCRI), cumprindo o papel de organizar politicamente as comunidades.

Finalmente, à maneira dos municípios, as comissões trabalham em áreas de trabalho específicas, de acordo com as necessidades locais, sendo as áreas de saúde e educação tomadas como prioritárias, ao modo do nível de governo municipal. A formação de professores, promotores de saúde ou outros cargos que requerem conhecimento específico pode contar com o apoio solidário de agrupações externas, sendo que aqueles já "formados" tendem a possuir um cargo fixo. Contudo, as funções político-administrativas não o são, isto é, possuem rotatividade, com mandatos que variam de acordo com a disponibilidade efetiva de zapatistas em cada comunidade.

Ainda que os sistemas autônomos de níveis municipal e comunitário, acima descritos, tenham sido otimizados em 2003, o principal trunfo da reforma não foi exatamente esse. Buscando reverter o processo de desenvolvimento espacialmente desigual do processo de autonomia, os zapatistas constituíram um terceiro nível de governo, então de âmbito regional. Dessa maneira, criaram-se cinco "zonas zapatistas", partindo das especificidades dos Marez. Assim, as autoridades de governo zapatista passaram a exercer suas funções em três diferentes escalas geográficas: a comunidade, o município e por fim a "zona", todas pautadas, insistimos, no princípio do "mandar-obedecendo". 
Em cada uma dessas zonas foi criado um "caracol"32, que funciona como uma espécie de centralidade administrativa, um espaço de encontro político e cultural entre os membros dos Marez e entre esses e a sociedade civil. Os caracóis possuem estrutura para hospedagem de zapatistas e visitantes, além de cozinhas coletivas, mercearias, galpões, escritórios com internet, oficina para consertos, quadras de esporte, cooperativas e, em alguns casos, rádios comunitárias, escolas e clínicas de saúde, entre outros.

Como elemento político coordenador dos diversos Marez de cada zona, criaram-se cinco "Juntas de Bom Governo" (JBG), as quais passaram a operar justamente nos espaços dos respectivos caracóis (mapa 2).

As juntas são compostas pelos delegados dos diversos "Conselhos municipais autônomos" e possui caráter civil, isto é, não é permitida a participação de membros do CCRI nem de qualquer um dos quadros militares zapatistas.

A JBG não possui poder deliberativo, mas sim o papel de articular a autonomia entre os diversos Marez que congrega, cabendo-Ihes funções como a gestão de recursos financeiros, o planejamento de obras e de capacitação pessoal, a mediação das comunidades rebeldes com a sociedade civil mexicana/internacional, o acompanhamento das decisões coletivas tomadas nas assembleias de base, a definição de competências, atribuições e vigilância nos órgãos de governo e nas entidades autônomas (em comum acordo com as comunidades representadas), a mediação de conflitos pela via do diálogo (internas à organização e entre zapatistas e não-zapatistas residentes nos Marez), entre outras (ORNELAS, 2005, p. 146).

Cada JBG é formada por um grupo que varia de 10 a 30 zapatistas, de acordo com as particularidades da zona e a quantidade de Marez que congrega. Busca-se na composição das JBG's uma igualdade numérica entre homens e mulheres, ainda que essa proporção nem sempre seja a que ocorre na prática, onde muitas vezes ainda vigora certa desproporcionalidade feminina. Todos os membros são eleitos por assembleia, com mandatos que

32 Os caracóis são uma herança direta dos Aguascalientes, espaços criados em 1994 pelos zapatistas para a interlocução entre as zonas rebeldes e a sociedade civil. A fundação dos caracóis significou um avanço no processo autonômico, já que se tornaram centralidades administrativas para o exercício da autonomia ao nível regional. Para mais informações recomendamos o artigo de Raúl Ornelas (2005) presente na bibliografia, inclusive já traduzido ao português. 

alternativa, pp. 158-195.

duram exatos três anos.

Mapa 2. Zonas de influência das "Juntas de Bom Governo", Chiapas, 2005

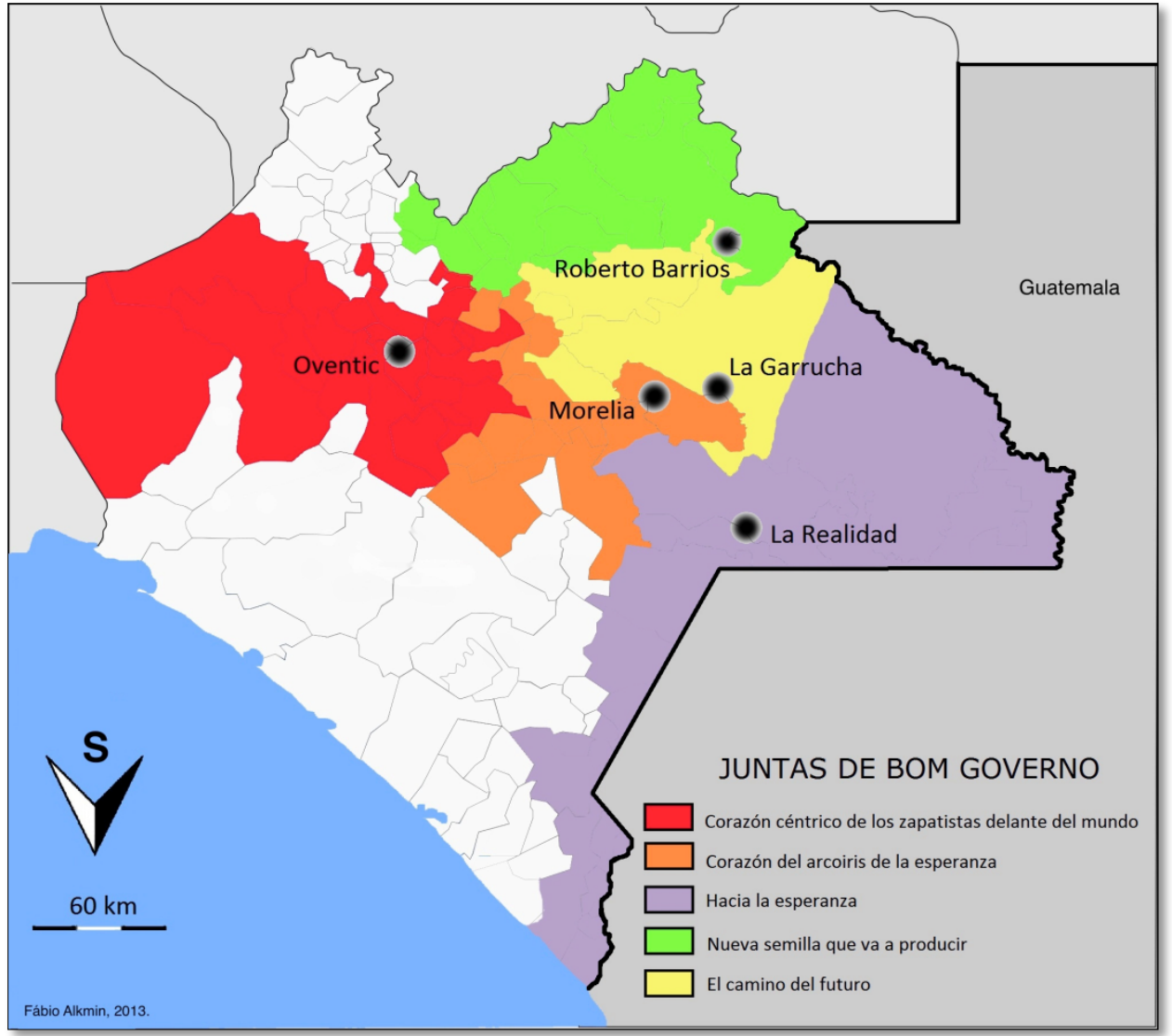

Mapa 2: Localização aproximada dos caracóis e a zona de influência das Juntas de Bom Governo (JBG) no estado de Chiapas, baseado em fontes de 2005. Fonte: Sistematização de Fábio Alkmin (2015), com base nos Comunicados do EZLN (2003), Ciepac e Sedesol (2005).

Estes membros se revezam em estadias que variam de uma semana a 15 dias nos caracóis, não recebendo qualquer tipo de salário por isso. Vale comentar que a não remuneração financeira aos cargos ou funções destinadas à comunidade é uma prática comum em todo o território onde vigora o governo zapatista (ainda que esta não tenha sido uma invenção do EZLN, remetendo à organização social típica das comunidades indígenas de Chiapas). A manutenção dessa prática, segundo argumenta o Subcomandante Marcos (2010, p. 43-44) busca impedir o nascimento de uma "classe política zapatista", isto é, o surgimento de aspirantes a cargos de governo com interesses estritamente financeiros ou particulares. 
Essa preocupação se reflete inclusive na não divisão entre o trabalho intelectual e manual - mesmo aqueles que possuem cargos de governo dividem sua rotina com a produção agrícola no campo - , com fins de impedir a formação de "políticos profissionais", que porventura poderiam acabar concentrando poder. Ao invés de pagamento em dinheiro, os membros de governo ou de comissões recebem uma espécie de "cooperação", tanto em trabalho como em espécie. Dessa maneira, como compensação às tarefas pertinentes a seu cargo político, os membros de sua comunidade suprem o tempo despendido nessas atividades trabalhando nos campos de sua família, contribuindo, além disso, com suporte material e proteção a mesma. Eventualmente a comunidade também pode colaborar com as despesas de transporte ao caracol, ou ainda com alimentos para sua estadia no mesmo. Esse aspecto é recorrente em todos os cargos zapatistas, desde o nível comunitário até o nível da zona.

Como podemos observar no organograma 1 , além de um setor estritamente administrativo, as JBG's também possuem áreas de trabalho em diversos campos de atuação (saúde, educação, produção etc.), as quais possuem o objetivo de articular as respectivas comissões nos níveis municipais.

As doações solidárias da sociedade civil (dinheiro, material de construção, equipamentos para projetos produtivos) necessariamente são dirigidas às JBG's, que definirão as comunidades mais necessitadas para tal. No que toca à gestão desses recursos, a JBG possui dois mecanismos de controle: a primeira é chamada de "filtro", a qual possui a função de revisar os relatórios financeiros publicados pela Junta. O segundo é a "Comissão de Vigilância Zapatista" (CVZ), que tem a responsabilidade de fiscalizar as atividades e prestações de contas da JBG. A CVZ é composta por bases de apoio de alguma das comunidades da zona, sem vínculos com os membros da Junta. Possuem, além disso, contato direto com os membros do CCRI da zona, para o qual reportam suas atividades e constatações ${ }^{33}$.

33 Assim sendo, o CCRI-CG (que como vimos é a instância política "superior" na organização zapatista) possui uma visão geral do processo autonômico em todas as zonas abarcadas pelos zapatistas, podendo corrigir desvios e/ou assessorar as áreas tidas como problemáticas, ainda que, segundo os comunicados zapatistas, não intervenham diretamente nas decisões tomadas nas assembleias de base. 
A "Comissão de informação", por sua vez, é a responsável por controlar o acesso de pessoas no caracol, além de registrar as doações solidárias, caso existam. Em certas circunstâncias a JBG recebe o apoio e assessoramento de entidades externas, especialmente em áreas que requerem conhecimentos específicos, como no caso de conflitos jurídicos, sistemas agroecológicos ou treinamento para promotores de saúde ou educação.

\section{Considerações finais}

Não podemos considerar o EZLN como o movimento que inaugura o debate pela autonomia indígena na América Latina, uma vez que a discussão já havia sido realizada em países como Nicarágua e Equador. Entretanto, seguramente o EZLN foi a organização responsável por aprofundar teoricamente a discussão à respeito, levando-a a um nível prático e cotidiano de extrema complexidade e organização. A manutenção e o controle dos territórios autônomos tornou-se até hoje um dos principais objetivos da resistência zapatista, e por extensão, de seu projeto autonômico. Em outras palavras, entendemos que os territórios autônomos tornaram-se o elemento constitutivo básico da estratégia autonômica do EZLN, a composição mais elementar desta, sem a qual todo seu projeto político torna-se comprometido.

Cabe destacar a singularidade dessa autonomia, aqui apresentada. Esta estratégia política é fruto de elementos singulares, extremamente específicos à conjuntura sócio-política de Chiapas, além da resposta militar, econômica e política do governo mexicano (o que inclui o descumprimento dos Acordos de San Andrés). Por tais razões, salienta-se que esta experiência não é uma fórmula e não nos parece generalizável, isto é, não pode ser tomada como um "modelo" por outros movimentos, fato inclusive reiterado pelos próprios zapatistas.

Isso não impede, entretanto, a apropriação por outros movimentos indígenas da ideia geral que sustenta a experiência zapatista: a demanda de uma maior autonomia política, entendida então como um maior controle 
sobre seus territórios e sobre as relações sociais ali estabelecidas, de forma a poderem exercer livremente seu exercício de autodeterminação. Nesse sentido, observa-se que a reivindicação por autonomia vem sendo incorporada na pauta política de outros movimentos indígenas da América Latina.

Embora este processo se dê de maneira extremamente particular para cada etnia, região e mesmo comunidade, tal fato parece indicar uma estratégia política alternativa dos movimentos indígenas contemporâneos frente as mazelas das políticas neoliberais e do capitalismo financeiro, ao mesmo tempo que um caminho possível para a perpetuação física e cultural das sociedades indígenas no interior dos Estados-nacionais contemporâneos.

\section{Referências bibliográficas}

ALKMIN, Fábio M. Por uma Geografia da autonomia: a experiência de autonomia territorial zapatista em Chiapas, México. São Paulo, 2015. Dissertação (Mestrado em Geografia Humana) - Faculdade de Filosofia, Letras e Ciências Humanas, Universidade de São Paulo.

ANAYA PEREZ, Marco Antonio; BATISTA ZANE, Refugio (coord.). iTodos somos Marcos! Historia del México Moderno y Contemporáneo. 2.ed. Chapingo, México: Universidad Autónoma Chapingo, 2001.

AUBRY, Andrés. Chiapas a contrapelo: una agenda de trabajo para su historia en perspectiva sistémica. México: Editorial Contrahistorias/ Centro (de estudios, información y documentación) Immanuel Wallerstein, 2005.

BARRIOS, Elizabeth Pólito; ESPONDA, Juan Gonzáles. Notas para comprender el origen de la rebelión zapatista. Revista Chiapas, México, n. 1, 1995. Disponível em: <http://www.ezln.org/revistachiapas/index>. Acesso em: 21 de out. 2001.

BRANCALEONE, C. Democracia, autogoverno e emancipação. Aproximações à práxis rebelde zapatista. In: CHAGUACEDA, ARMANDO; BRANCALEONE, Cassio. (Org.). Sociabilidades emergentes y movilizaciones sociales en América Latina. 1ed. Buenos Aires: CLACSO, 2012b, v. 1, p. 141-154.

BRANCALEONE, Cassio. Sobre o significado da experiência de autogoverno zapatista. Rio de Janeiro, 2012a. 363 p. Tese (Doutorado em Sociologia). Instituto de Estudos Sociais e Políticos, Universidade do Estado do Rio de Janeiro (UERJ).

CASANOVA, Pablo Gonzáles. Causas da rebelião em Chiapas. México. Disponível em: <http://www.ufba.br/ revistao/03casano.html>. 

alternativa, pp. 158-195.

Acesso em: 16 de out. 2001.

CIACH, CONPAZ; SIPRO. Para entender Chiapas. México: Imprentei, 1997. COMANDANTE DAVID. Discurso pronunciado con motivo a la creación de los Caracoles y Juntas de Buen Gobierno, 9 de agosto de 2003. Chiapas, México. Disponível em: <http://palabra.ezln.org.mx/comunicados/2003/2003_08_09_c.htm> . Acesso em 17 de nov. de 2015.

DE JESUS, Graziela Menezes. "Para todos, tudo! Para nós, nada!" o Poder nos discursos do Exército Zapatista de Libertação Nacional. Vitória: UFES, 2007. Dissertação (mestrado em História). Programa de Pós-Graduação em História Política das Relações Econômicas, PPGHIS, Universidade Federal do Espírito Santo.

DÍAZ, Carlos Tello. Chiapas: La Rebelíon de Las Cañadas. Madrid: Acento Editorial, 1995.

DIÁZ-POLANCO, Héctor. La rebelión de los indios zapatistas y la autonomía. In: CHOMSKY, Noam (et al.). Chiapas Insurgente: 5 ensayos sobre la realidad mexicana. México: Editorial Txalaparta, 1997.

EZLN. Documentos y comunicados (Libro I). Colección Problemas de México, 6a. Reimpresión. México: Ed. Era, 2003 (1a. Ed. 1994).

EZLN. Gobierno Autónomo I: Cuaderno de texto de primer grado del curso de "La libertad según I@s Zapatistas". Chiapas, México, 2013.

FERNÁNDEZ, Paulina C. Gobierno autónomo zapatista: características antisistema político mexicano. Texto produzido em ocasião do Seminario Internacional de reflexión y análisis. San Cristóbal de las Casas: Universidad de la Tierra, 31 de diciembre de 2009. Disponível em: <http://goo.gl/DPtHPh>. Acesso em: $1^{\circ}$ mar.2014.

GENNARI, Emilio. EZLN: Passos de uma rebeldia. São Paulo: Expressão Popular, 2005.

GILLY, Adolfo. Chiapas la razón ardiente: Ensayo sobre la rebelión del mundo encantado. 2. ed. México: Ediciones ERA, 2002.

HAESBAERT, Rogério; LIMONAD, Ester. O território em tempos de Globalização. etc.... espaço, tempo e crítica, Rio de Janeiro, v. 1, n. 2, p. 39-52, ago. 2007.

HÉAU-LAMBERT, Catherine; RAJCHENBERG, Enrique. História y simbolismo en el movimiento zapatista. Revista Chiapas, México, n. 1, 1995. Disponível em: <http://www.ezln.org/revistachiapas1/index>. Acesso em: 16 de out. 2001.

LE BOT, Yvon. O Sonho Zapatista. Tradução de Pedro Baptista. Portugal: Edições Asa, 1997.

LEÓN, Antonio García de. Resistencia y Utopía. Memorial agraviados y crónica de revueltas y profecías acaecidas en la provincia de Chiapas durante los últimos quinientos años de su historia. México: ERA, 1985, tomo II. 
MORAES, Antônio C. R. Capitalismo, Geografia e Meio Ambiente. São Paulo, 2000. Tese (Livre Docência). Faculdade de Filosofia, Letras e Ciências Humanas, Universidade de São Paulo.

ORNELAS, Raúl Bernal. A autonomia como eixo da resistência zapatista. Do levante armado ao nascimento dos caracoles. In: CECEÑA, Ana Esther (Org.). Hegemonias e emancipações no século XXI. Consejo Latinoamericano de Ciencias Sociales (CLACSO), 2005. Disponível em: <http://bibliotecavirtual.clacso.org.ar/clacso/gt/20101018124258/8or nelas.pdf >. Acesso em: 21 de jun. 2006.

RAFFESTIN, Claude. Por uma geografia do poder. São Paulo: Editora Ática, 1993.

REYES RAMOS, Maria Eugenia. Reconfiguración del espacio agrario en Chiapas: las consecuencias del levantamiento zapatista. In: PÉREZ RUIZ, Maya Lorena (coord.). Tejiendo historias: Tierra, género y poder en Chiapas. México: INAH, 2004.

RICÁRDEZ, Rubén Jiménez. Las razones de la sublevación. Disponível em: <http://www.ezln.org /revistachiapas3>. Acesso em: 23 de out. 2001.

SeCretaría de desarRollo social (SEDESOL). Programa estatal de ordenamiento territorial do estado de Chiapas. México: 2005. Disponível em: <http://goo.gl/yccEKp>. Acesso em: 20.jan.2013.

SOLÍS, Daniel Villafuerte (et al). La tierra en Chiapas: viejos problemas nuevos. México: Fondo de Cultura Económica, 2002.

SOLÍS, Daniel Villafuerte; SOLANO, José Montero. Chiapas: la visión de los actores. México: Casa Juan Pablos, Universidad de Ciencias y Artes de Chiapas, Interpeace, 2006.

SOUZA, Marcelo L. O Território: sobre espaço e poder, autonomia e desenvolvimento. In: CASTRO, I. E. De; GOMES, P. C. da C.; CORRÊA, R. L. (orgs). Geografia: Conceitos e temas. Rio de Janeiro: Bertrand Brasil, 1995. p. 77-115.

SUBCOMANDANTE MARCOS. O guerrillero en el asfalto. Entrevista concedida a Eduardo Blasina. México, 15 de março de 2001. Disponível em: <http://palabra.ezln.org.mx/comunicados/2001/2001_

03_15_b.htm>. Acesso em: 23 maio 2005.

SUBCOMANDANTE MARCOS. Entrevista concedida à agrupação Kilombo Intergaláctico, (jan. 2007) In: Sin Referente: Una Entrevista con EI Subcomandante Insurgente Marcos. Durham: PaperBoat Press, 2010. 